\title{
DESIGN COM FOCO NO USUÁRIO: DESENVOLVIMENTO DE UNIFORME PARA PRESTADORES DE SERVIÇOS DE LIMPEZA
}

\author{
Lívia Blanch Batista \\ SENAI CETIQT \\ liviablanch@globo.com \\ Marilia Pontes Franco \\ SENAI CETIQT \\ mariliapontes23@yahoo.com.br \\ Natalia Strauch de Andrade \\ SENAI CETIQT \\ nataliastrauchdeandrade@gmail.com \\ Paola de Lima Vichy \\ SENAI CETIQT \\ paolavichy@gmail.com
}

Resumo: A Moda, não só como viés de materialização, no vestuário, da criatividade humana, mas enquanto objeto de estudo por métodos de Design, ainda é um ramo recente. Por conta disso e da grande carga lúdica que envolve seu processo de criação, ela ainda carece de produção acadêmica extensiva, especialmente quanto à descrição das etapas e procedimentos projetuais pelos quais o produto final passa antes de ser comercializado. Inclusive, persiste a necessidade de investigação nesse campo, pois os modelos de referência metodológicos em Design são, geralmente, voltados para o projeto de desenvolvimento de um objeto, com olhar para as características dele, tecnologias e processo produtivo. Além disso, o atual cenário mundial, de uma maneira ampla, também é marcado por um aspecto de complexidade, em que se fazem presentes distintas variáveis, como a comunicação veloz, o excesso de informações, e, consequentemente, o aumento de demanda em satisfazer novos e constantes desejos das pessoas. Assim, o Design Thinking foi proposto como uma nova forma de olhar o caminho de projeto em Design, tendo como ponto-chave do projeto o foco no usuário do produto final, visando um estudo mais aprofundando do comportamento do público alvo/consumidor, compreendendo as interações de cada indivíduo em seus grupos para criar "com" as pessoas observadas, não mais para elas. Portanto, o objetivo deste trabalho é apresentar o desenvolvimento e resultado da aplicação dessa metodologia no projeto de novos uniformes da equipe que realiza a limpeza e manutenção das unidades do SENAI CETIQT, na disciplina de Métodos e Processos em Design, do segundo período do curso de Design de Moda. A ideia era propor novos modelos de 
uniformes masculino e feminino, para uso no verão e no inverno, que seriam destinados exclusivamente a tal equipe. Como esse serviço é prestado através de terceirização, alguns requisitos gerais precisaram ser considerados de modo a criar um produto com foco nas necessidades e demandas dos usuários, mas que também alinhasse a identidade visual do SENAI CETIQT a da prestadora contratada. Todas as etapas de estudo, incluindo o processo criativo, foram registradas, visando demonstrar como se deu o desenvolvimento do projeto. $O$ início se deu com a construção de um briefing para entender as premissas dele; a seguir, foram realizadas pesquisas sobre a prestadora do serviço, identificando seus clientes, serviços e sua identidade; foram então levantados outros uniformes para limpeza, sendo analisados os quesitos de funcionalidade, cores, materiais, com pontos positivos e negativos; após, passou-se para a pesquisa dos usuários - foco do projeto - utilizando-se de diversas ferramentas para entender as reais necessidades deles em relação ao produto. Realizou-se entrevistas individuais com os colaboradores, observação das tarefas e análise do uniforme em uso. Essas informações foram esquematizadas em painéis visuais, palavras-chave e tabelas que foram traduzidas em requisitos para o projeto. Por fim, foram desenvolvidos os croquis dos modelos definitivos e suas especificações técnicas. A proposta final para o novo uniforme aliou tecnologia, funcionalidade, ergonomia e estética, enfim integrando as demandas e necessidades declaradas e latentes dos usuários aos requisitos do projeto.

Palavras-chave: Design Thinking, usuário, uniforme, serviço de limpeza 